\title{
KONDISI HATI TIKUS BETINA AKIBAT INDUKSI 7,12-DIMETHYL BENZ( $\alpha$ )ANTHRASEN (DMBA) DAN PENYEMBUHANNYA DENGAN PROPOLIS DAN NANOPROPOLIS INDONESIA
}

\author{
Akhmad Endang Zainal Hasan ${ }^{1,2}$, E. Mulyati Effendi ${ }^{2}$, Agus Setiyono ${ }^{3}$, dan Bayu Sandi ${ }^{2}$ \\ ${ }^{1)}$ Departemen Biokimia, FMIPA IPB \\ ${ }^{2)}$ Program Studi Farmasi FMIPA UNPAK, BOGOR \\ ${ }^{3)}$ Departemen Klinik, Reproduksi dan Patologi, FKH, IPB \\ Email : zainalhasan@ipb.ac.id; pakzainalhasan@gmail.com
}

\begin{abstract}
ABSTRAK
Tujuan dari penelitian ini adalah menentukan efek farmakologis propolis dan nanopropolis untuk pengobatan penyakit hati pada tikus betina yang diinduksi senyawa karsinogenik 7,12 - dimetilbenz $(\alpha)$ antasena (DMBA). Penelitian dilakukan dengan mengamati histopatologi dan makroskopik hati pada 28 ekor tikus betina galur Sprague - Dawley. Tikus percobaan dibagi menjadi 7 kelompok perlakuan dengan 6 kelompok yang diinduksi DMBA (Kelompok I- VI ) dan 1 kelompok sebagai kontrol normal. Kelompok I sebagai kontrol negatif diberi $1 \mathrm{ml} \mathrm{NaCl}$ secara injeksi intraperitoneal (ip). Kelompok II - IV diberi nanopropolis 8; 32 dan 56 ppm ip. Kelompok V diberi ekstrak ethanol propolis 233 ppm ip, kelompok VI sebagai kontrol positif diberikan doxorubixin ip dan kelompok VII sebagai kontrol normal diberi penyediaan akuades. DMBA diinduksi selama 11 minggu dan pengobatan dilakukan 15 minggu. Setiap minggu tikus ditimbang bobotnya dan diperiksa terhadap inisiasi tumor. Hasil penelitian menunjukkan bahwa ekstrak etanol propolis $233 \mathrm{ppm}$ dan nanopropolis konsentrasi 32 dan 56 ppm dapat mempertahankan kondisi optimal hati tikus. Efeknya adalah setara dengan kontrol normal.
\end{abstract}

Kata kunci: penyakit hati, DMBA, histopatologi, propolis, nanopropolis

\begin{abstract}
The purpose of this study is to determine the pharmacological effects of propolis and nanopropolis as treatment of liver disease on carcinogenic substances 7,12dimethylbenz $(\alpha)$ antacene (DMBA) induced female rat. The research conducted by observing liver histopathology and macroscopic on 28 female rat strain Sprague-Dawley. The rats divided into 7 treatment groups with 6 groups of DMBA-induced rats (Group I-VI) and 1 group of as control normal rats. Group I as negative control was given $1 \mathrm{ml} \mathrm{NaCl}$ intraperitoneal (ip) injection. Group II-IV was given nanopropolis 8; 32 and $56 \mathrm{ppm}$ ip, respectively. Group V was given ethanol extract of propolis $233 \mathrm{ppm}$ ip, group VI as positive control was given doxorubixin ip and group VII as normal control was given distilled water provision. DMBA was induced during 11 weeks period and treatment was performed 15 weeks. The rat was weighted and examined the initiation of tumors every week. The results showed that the ethanol extract of propolis $233 \mathrm{ppm}$ and nanopropolis concentration of 32 and $56 \mathrm{ppm}$ could maintain optimal conditions of rat's liver. The effect was equivalent with normal control.
\end{abstract}

Key Words : liver disease, DMBA, liver histopathology, propolis, nanopropolis 


\section{PENDAHULUAN}

Seiring berkembangnya zaman, masyarakat dihadapkan dengan perilaku seksual, infeksi obat-obatan medis, merokok, radiasi sinar Ultra Violet dan diet yang dapat memicu penyakit kanker (Doll \& Peto, 1981). Pengobatan yang ada saat ini dengan menggunakan obat-obatan kimia mulai dirasa oleh sebagian masyarakat kurang tepat karena dapat menyebabkan efek negatif bagi tubuh, baik secara langsung maupun tidak langsung. Implikasi dari hal tersebut maka masyarakat mencari pengobatan alternatif yang aman dan berkhasiat sehingga menguatlah konsep back to nature atau kembali ke alam.

Hati merupakan organ yang sangat penting dan sebagi pusat metabolisme tubuh yang mempunyai banyak fungsi untuk mempertahankan tubuh yaitu dengan cara detoksifikasi. Detoksifikasi merupakan sistem pertahanan tubuh terhadap masuknya senyawa kimia asing (xenobiotik). Jika xenobiotik tersebut berhasil lolos pada proses detoksifikasi, maka kemungkinan menjadi toksik dan jika berlebihan akan bereaksi dengan sel reseptor atau sel sasaran yang bersifat reversibel maupun irreversibel. Akibatnya akan timbul efek toksik yang tidak diinginkan (Donatus, 2001).

Senyawa 7,12-dimetilbenz $(\alpha)$ antrasen (DMBA) adalah zat kimia yang termasuk dalam Polycyclic Aromatic Hydrocarbon (PAH) yang dikenal bersifat mutagenik, teratogenik, karsinogenik, sitotoksik dan immunosupresif (Clement, et al. 1980). Hati yang terpapar DMBA akan menunjukkan perubahan sel hati, gambaran histologi hati dengan pemberian DMBA $25 \mathrm{mg} / \mathrm{kg}$ BB selama 90 hari menunjukkan perubahan bentuk normal menjadi tidak normal (Budi, 2010; Vijayabaskaran, et al., 2010).

Bahan alam yang dipercaya dapat bersifat hepatoprotektif salah satunya adalah propolis, yaitu bahan perekat dari resin yang dikumpulkan lebah pekerja dari kuncup, kulit kayu dan bagian tumbuhan lainnya (Gojmerac, 1983). Propolis berwarna kuning sampai coklat tua, bahkan ada yang transparan. Komponen penting dalam propolis berupa resin (turunan asam benzoat dan flavonoid), lilin dan asam lemak, minyak esensial, polen dan mineral-mineral. Flavonoid yang dikandung dalam propolis memberikan respon terhadap aktivitas antibakteri, serta antikanker dan berperan dalam imunodulisasi tubuh (Bankova, et al., 2000; Bankova, et al., 2002; Burdock, 1998; Sforcin, 2007). Kandungan senyawa aktif pada propolis memperlihatkan efek hepatoprotektif karena memiliki aktifitas antiradikal bebas yang dapat mengurangi wilayah induksi kerusakan hati dan jumlah GGT + AHF (Perez, et al., 2012). Propolis juga memiliki aktivitas imunodulator dan aktivitas antiinfeksi non spesifik melalui aktivasi makrofag (Dimov, et al., 1991).

Propolis sebagai pengobatan kerusakan hati belum banyak diteliti. Organ hati mempunyai potensi sebagai indikator perbaikan maupun kerusakan akibat senyawa sitotoksik karena secara aktif berperan dalam mekanisme aktivasi DMBA yang melibatkan enzim sitokrom P450 isoform CYP1A1 (Colon, et al., 1999). Efek kerusakan jaringan hati akibat induksi DMBA dapat terlihat jelas pada gambaran histologinya (Vijayabaskaran, et al., 2010)

Tujuan penelitian ini adalah mengetahui efek farmakologis propolis dan nanopropolis Indonesia sebagai penyembuhan organ hati yang terinisiasi zat karsinogenik (DMBA).

\section{METODE PENELITIAN}

Penelitian ini dilaksanakan pada bulan Juni - Oktober 2012 bertempat di Laboratorium Farmasi, Fakultas Matematika dan Ilmu Pengetahuan Alam Universitas Pakuan di Bogor, juga di Laboratorium Patologi, Departemen Klinik, Reproduksi dan Patologi Fakultas Kedokteran Hewan Institut Pertanian Bogor.

\section{Bahan}

Propolis kasar Trigona spp. yang berasal dari Pandeglang (Banten), etanol $70 \%, \beta$-siklodekstrin, buffer fosfat $50 \mathrm{mM}$

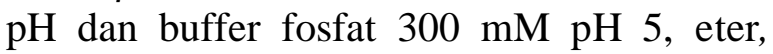
aquadest, tikus percobaan yaitu tikus putih 
betina (Rattus norvegicus) galur Sprague Dawley, 7,12-dimetilbenz( $\alpha$ )antrasen atau DMBA, minyak zaitun (Olive Oil), buffer formalin $10 \%$, paraffin, minyak imersi, pewarnaan sediaan histologik (hematoksilin dan eosin).

\section{Cara Kerja}

Pembuatan Ekstrak Etanol Propolis Trigona spp.

Sarang lebah Trigona spp. dari Pandeglang, Banten, Indonesia. Sampel disimpan dalam toples vakum. Sarang lebah dibersihkan dari pengotor, setelah itu diekstraksi menggunakan etanol $70 \%$ selama 24 jam. Ekstraksi dan pengujian pendukung dilakukan sesuai dengan modifikasi dari Pietta, et al., 2002 yaitu pembuatan nanopropolis, penentuan aktivitas hepatoprotektif, penentuan aktivitas hepatoprotektor, pengamatan patologi dan anatomi hati secara makroskopik.

\section{Pembuatan Nanopropolis}

Pembuatan nanopropolis sesuai dengan tata cara penelitian yang dilakukan oleh Hasan, et al., 2011 dan modifikasi dari Mohanraj dan Chen, 2006. Metode yang digunakan yaitu mendispersikan ke bentuk polimer, kemudian polimerisasi dari monomer dan pembentukan atau koaservasi polimer hidrofilik.

\section{Hewan Coba}

Hewan percobaan yang digunakan adalah 28 ekor tikus putih betina dengan bobot badan rata-rata 120-130 g. Tikus percobaan dilakukan pengelompokan secara random menjadi 7 kelompok perlakuan, masing-masing 4 ekor dalam tiap kandang. Tikus tersebut dikandangkan secara terpisah di dalam kandang berbentuk kotak plastik, dengan tutup kawat yang mudah dibuka. Alas kandang dialasi dengan sekam bekas gerabah padi yang harus diganti setiap hari agar kondisi kandang tetap kering dan sehat. Tikus diadaptasikan di kandang hewan Laboratorium Patologi, Departemen Klinik, Reproduksi dan Patologi FKH selama 7 hari. Selama penelitian semua kelompok tikus diberi pakan standar dan air secara $a d$ libitum.

\section{Penentuan Aktivitas Hepatoprotektif Induksi DMBA}

Hewan coba diadaptasikan di kandang percobaan selama 1 minggu sebelum diberikan perlakuan. Tikus dibagi menjadi 2 kelompok, kelompok perlakuan DMBA sebanyak 24 ekor dan kelompok perlakuan kontrol normal sebanyak 4 ekor. Kelompok pertama yaitu kelompok perlakuan kontrol dengan menyuntikkan $1 \mathrm{~mL}$ garam fisiologis secara intraperitonial. Kelompok kedua diberi perlakuan DMBA dengan menyuntikkan DMBA dosis $25 \mathrm{mg} / \mathrm{kg}$ BB menggunakan pelarut minyak zaitun secara intraperitonial. Induksi dilakukan selama 11 minggu, tiap minggu hewan coba ditimbang dan dipalpasi untuk mengecek adanya inisiasi kanker.

\section{Aktivitas Hepatoprotektor}

Sebanyak 24 ekor tikus yang telah disuntik DMBA dan diketahui terinisiasi sel kanker lewat palpasi dikelompokkan menjadi 6 kelompok, sedangkan tikus yang tidak disuntik DMBA dikelompokkan dalam Kelompok Kontrol Normal (disuntik $1 \mathrm{~mL}$ garam fisiologis), pengelompokan sebagai berikut :

Kelompok 1 : Kelompok Kontrol Negatif, disuntik dengan $1 \mathrm{~mL}$ garam fisiologis.

Kelompok 2 : Kelompok Perlakuan 1, disuntik nanopropolis 8 ppm.

Kelompok 3 : Kelompok Perlakuan 2, disuntik nanopropolis $32 \mathrm{ppm}$.

Kelompok 4 : Kelompok Perlakuan 3, disuntik nanopropolis $56 \mathrm{ppm}$.

Kelompok 5 : Kelompok Perlakuan 4, disuntik Propolis 233 ppm.

Kelompok 6 : Kelompok Kontrol Positif, disuntik dengan doksorubisin.

Kelompok 7 : Kelompok Kontrol Normal, disuntik $1 \mathrm{~mL}$ garam fisiologis.

\section{Inhibition Concentration ( $\left.\mathrm{IC}_{50}\right)$} didapatkan dari penelitian yang dilakukan oleh Hasan, et al., 2011 yang menunjukkan bahwa nanopropolis Pandeglang mempunyai niai IC $_{50}$ pada sel kanker MCF-7, pada 
konsentrasi dibatas 8 ppm sedangkan EEP (Ekstrak Etanol Propolis) mempunyai nilai $\mathrm{IC}_{50}$ pada konsentrasi lebih dari 100 ppm.

Pada hari ke 60 dari penyuntikkan (nanopropolis, EEP, garam fisiologis dan doksorubisin), maka penelitian dihentikan. Semua tikus diambil untuk dilakukan analisis histopatologi.

\section{Pengamatan Patologi dan Anatomi Hati Secara Makroskopik}

Pengamatan makroskopik hati pada tikus meliputi warna, permukaan dan konsistensi. Hati yang normal berwarna merah kecoklatan, permukaannya licin dan konsistensinya kenyal (Anggraini, 2008). Kriteria normal bila tidak ditemukan:

a. Perubahan warna

b. Perubahan struktur permukaan

c. Perubahan konsistensi

Derajat kerusakan hati:

0 = tidak terjadi perubahan

$+\quad=$ bila ditemukan 1 kriteria diatas

$++=$ bila ditemukan 2 kriteria diatas

$+++=$ bila ditemukan 3 kriteria diatas

\section{Pembuatan dan Pemeriksaan Jaringan Hati Secara Mikroskopik}

Sampel jaringan hati dibuat sediaan histologi. Hati yang telah dicuci dengan larutan $\mathrm{NaCl}$ fisiologis $0,9 \%$, lalu difiksasi dengan larutan Bouin selama 12 sampai 24 jam kemudian diblok dengan paraffin, setelah didehidrasi dengan serial alkohol (70, 80, 90, $100 \%$ ) dan clearing dengan xylol (I, II, III). Blok paraffin disayat dengan mikrotom setebal 5 mikron. Sayatan yang baik diletakkan pada gelas objek, kemudian dilakukan pewarnaan Hematoksilin Eosin (HE). Pengamatan histologi hati meliputi, granula sitoplasma, degenerasi dan sel neoplastik (Vijayabaskaran, et al., 2010).

Setiap preparat organ diamati di bawah mikroskop dalam 5 lapangan pandang, yaitu pada ke empat sudut dan bagian tengah preparat, dengan perbesaran sebesar 400x. Data yang dikumpulkan berupa data primer (granula sitoplasma, degenerasi dan sel neoplastik) dari hasil penilaian gambaran histopatologi hepar tikus betina SpragueDawley, kemudian dinilai indeks histopatologinya. Indeks histopatologi hepar dinilai dengan modifikasi sistem Knodell Score.

Hasil analisis diuji dengan uji statistik non parametrik Kruskal Wallis. Nilai $p$ bermakna jika $p>0,05$. Data yang diperoleh diolah dengan menggunakan program SPSS 15.0 for Windows (Sariningrum, 2008).

\section{HASIL DAN PEMBAHASAN}

Pengamatan melihat Organ Hati (Gambar 1) secara makroskopis sebagai indikator faal tubuh dalam fungsi pertahanan tubuh (Dalimartha \& Setiawan, 2005).

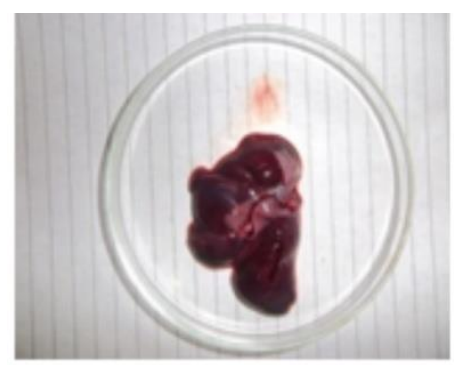

(a)

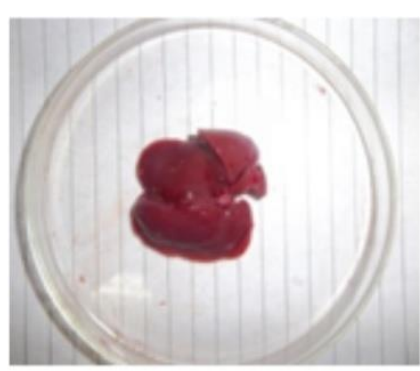

(b)

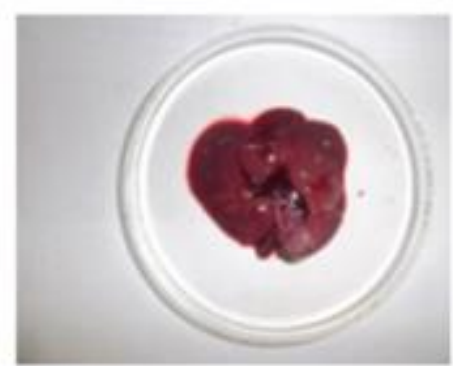

(c) 


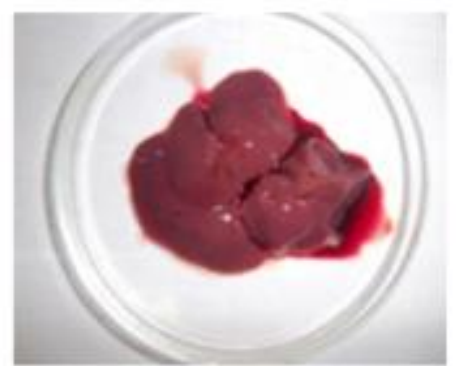

(d)

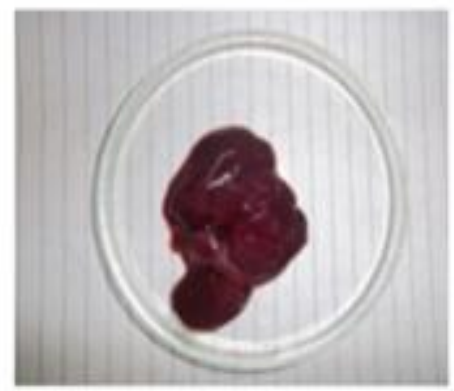

(e)

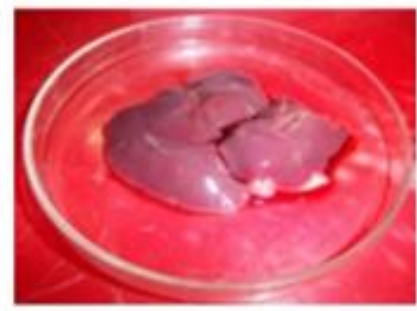

(g)

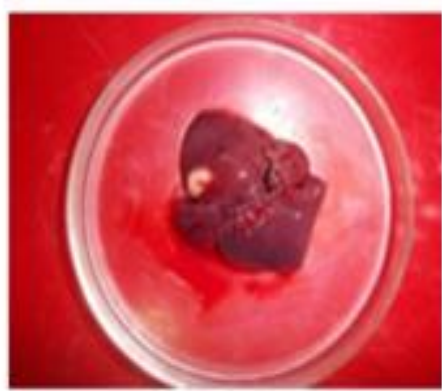

(f)

Gambar 1. Pengamatan Makroskopis Hati Tikus

Keterangan: Organ Hati (a) Kelompok Normal, (b) Kelompok 56 ppm Nanopropolis, (c) Kelompok 32 ppm Nanopropolis, (d) Kelompok 8 ppm Nanopropolis, (e) Kelompok Propolis, (f) Kelompok DMBA,(g) Kelompok Doksorubisin

Pada pengamatan organ hati secara makroskopis, terlihat bahwa organ tikus kelompok yang sudah di induksi DMBA berbeda warnanya jika dibandingkan dengan kontrol normal, namun untuk permukaan dan konsistensinya relatif sama. Hal ini menunjukkan bahwa DMBA bersifat sitotoksik sejalan dengan penelitian yang dilakukan oleh Scott, et al. 1993.

Pengamatan dilanjutkan dengan histopatologi hati sebagai indikator penilaian yaitu tingkat kerusakan sel hati pada umumnya. Hasil pengamatan terlihat pada Gambar 2.

Gambaran dari histopatologi memperlihatkan kondisi jaringan hati yang sehat (a) ditandai dengan hepatosit yang mengarah ke arah vena sentralis tersusun secara radial, bentuk dari membran sel masih utuh dengan sitoplasma didalamnya dan sel hepatosit tersusun dengan jelas kondisi yang kurang lebih sama terlihat pada propolis (b) dan kelompok doksorubisin (g) kondisi yang cukup baik terlihat pula pada kelompok 56 ppm (c) dan kelompok 32 ppm (d). Hasil yang menunjukkan perbaikkan ini sesuai dengan penelitian Carrasco et al., 2006.

Terlihat pada kelompok Doxorubisin (g), Propolis (b) dan 56 ppm (c) serta 32 ppm (d) kondisi histopatologi hatinya baik, hepatosit terlihat jelas dan tersusun secara radial, walaupun masih ditemukannya butirbutir lemak, kondisi hepatosit yang baik karena pengaruh pemberian propolis, senyawa antioksidan dan flavonoid dalam propolis dan nanopropolis memberikan efek perbaikan sel-sel hati dengan relatif cepat.

Kerusakan sel hati kelompok DMBA pada kontrol negatif yang terjadi meliputi nekrosis, dan degenerasi butir-butir lemak. Nekrosis merupakan pecahnya sel hepatosit sehingga seluruh isi sel keluar dari sel akibat rusaknya lapisan semipermiabel yang melindungi sel serta degradasi butir-butir lemak disebabkan adanya senyawa toksik yang menurunkan fungsi lipolitik hati, hal ini 


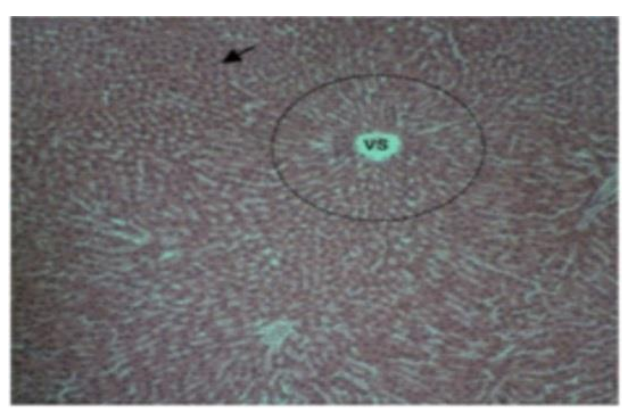

( a )

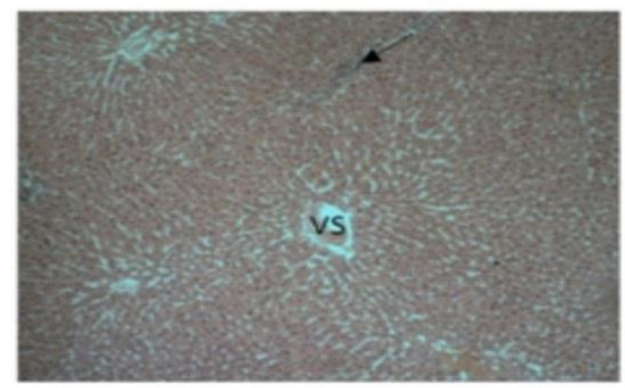

(c)

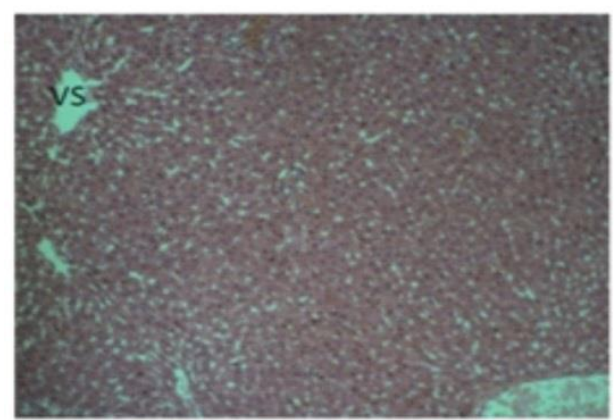

( e )

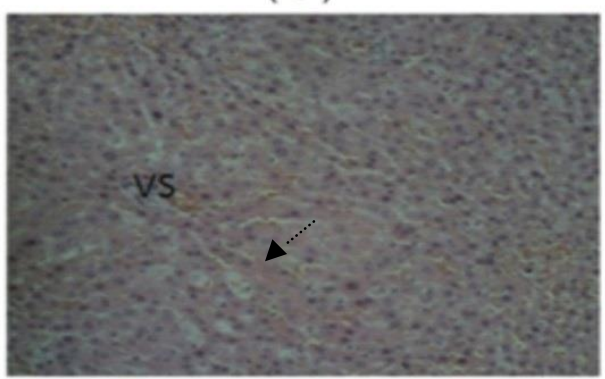

(g)

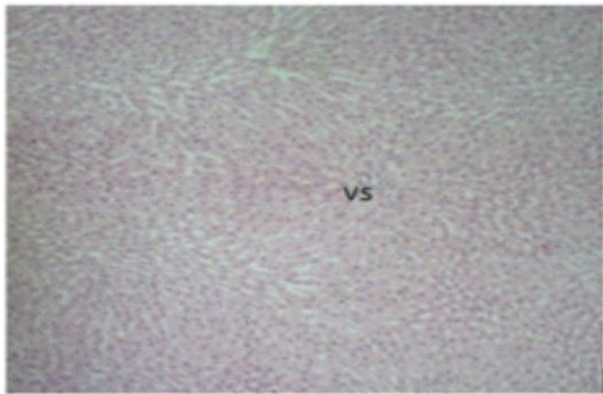

( b )

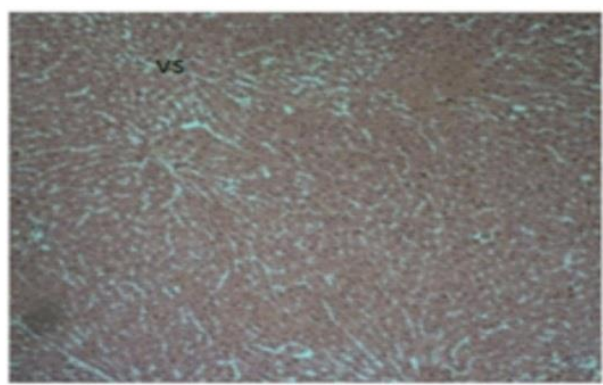

(d)

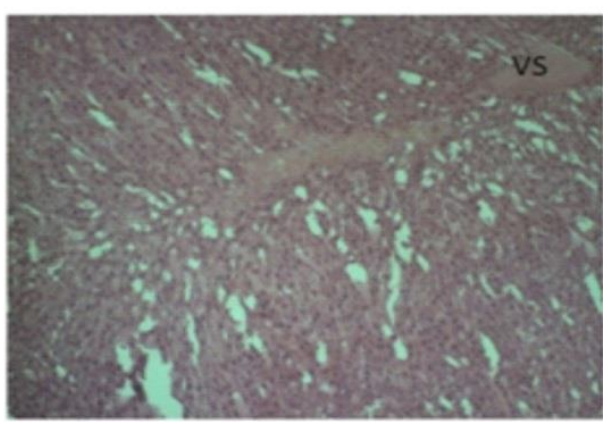

( f )

Gambar 2. Histopatologi Hati

Keterangan: Kelompok Normal (a), Kelompok EEP (b), Kelompok nanopropolis 56 ppm, 32 ppm, 8 ppm (c), (d), (e), Kelompok DMBA (f), Kelompok Doxorubisin (g) (VS: vena sentral, anak panah : hepatosit, anak panah putus-putus: nekrosis, panah bulat : butir lemak) (Pewarnaan HE, perbesaran objektif 10x)

sejalan dengan penelitian yang dilakukan oleh Scott et al., 1993 yang menyatakan bahwa DMBA merupakan senyawa yang bersifat sitotoksik

Kondisi histopatologi untuk kelompok propolis, menunjukkan adanya perbedaan bila dibandingkan dengan nanopropolis, seperti terlihat pada Gambar 3. Hal ini disebabkan karena konsentrasi nanopropolis yang relatif kecil dibandingkan dengan konsentrasi propolis tanpa nanopartikel. 


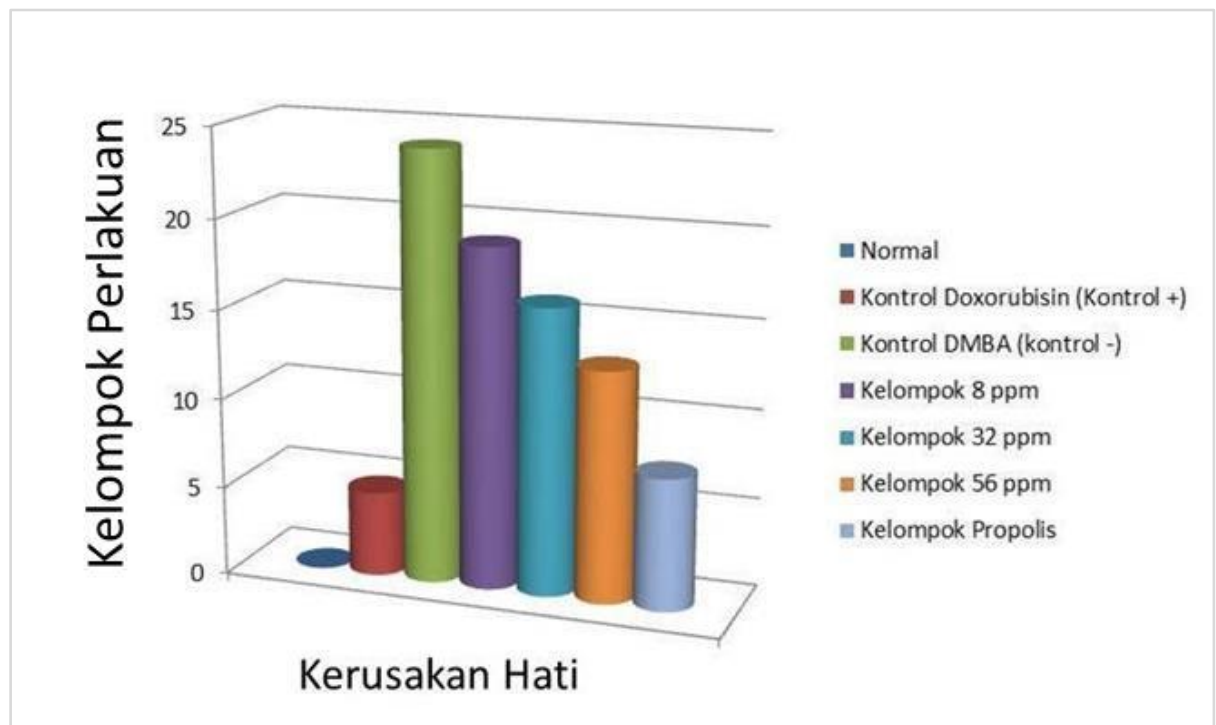

Gambar 3. Grafik Penilaian Persentase Kerusakan Histopat Hati Tikus Akibat Pemberian Nanopropolis Dan Propolis

Hasil skoring dari grafik memperlihatkan perbedaan kerusakan tiap kelompok dibandingkan dengan kontrol normal terlihat bahwa kerusakan kelompok Propolis tidak memiliki nilai yang jauh berbeda dengan kontrol positif dalam kerusakan jaringan hati, dilanjutkan dengan kontrol $56 \mathrm{ppm}, 32 \mathrm{ppm}$ dan $8 \mathrm{ppm}$, dan kontrol negatif. Hal ini menunjukkan bahwa propolis dengan konsentrasi $233 \mathrm{ppm}$ dan nanopropolis dengan konsentrasi $56 \mathrm{ppm}$ menunjukkan hasil yang hampir sama dalam mengurangi pengaruh negatif dari induksi DMBA dan memperbaiki kondisi hati. Dengan demikian dapat dikatakan bahwa propolis dan nanopropolis dapat digunakan dalam menghilangkan pengaruh buruk dari bahan karsinogen yang masuk ke dalam tubuh.

Berdasarkan hasil uji statistik kelompok $32 \mathrm{ppm}, 56 \mathrm{ppm}$, dan propolis tidak bebeda secara signifikan dengan control positif, sedangkan kelompok $8 \mathrm{ppm}$ dan kontrol negatif berbeda secara signifikan dengan kontrol positif. Kelompok kontrol positif, $32 \mathrm{ppm}, 56 \mathrm{ppm}$, dan propolis berbeda secara singifikan dengan kelompok kontrol negatif, sedangkan kelompok 8 ppm tidak berbeda secara signifikan dengan kontrol negatif.

\section{SIMPULAN}

Pemberian Propolis dan nanopropolis selama 60 hari memberikan efek farmakologi pada hati hewan coba yang diinduksi DMBA.

Pada pengamatan organ hati secara makroskopis, organ hati tikus yang terinduksi DMBA terlihat berbeda warna dibandingkan kontrol normal, namun untuk permukaan dan konsistensi relatif sama.

Berdasarkan pengamatan histopatologi hati hasil uji analisis statistik non-parametrik Kruskal Wallis terlihat kelompok doksorubisin (control positif), kelompok propolis, kelompok nanopropolis konsentrasi 32 dan 56 ppm, memiliki kondisi hepatosit yang relatif baik, hepatosit terlihat jelas dan tersusun radial, walaupun masih ditemukannya butir-butir lemak.

Kandungan propolis baik dalam bentuk bukan nanopropolis maupun nanopropolis yaitu flavonoid memberikan efek perbaikan sel-sel hati.

Kelompok yang berpotensi secara farmakologis yang baik untuk penyembuhan hati yang terinduksi DMBA adalah kelompok propolis konsentrasi $233 \mathrm{ppm}$ dan nanopropolis konsentrasi 32 dan 56 ppm.

\section{DAFTAR PUSTAKA}

Anggraini, D.R. 2008. Gambaran Makroskopik dan Mikroskopik Hati 
dan Ginjal Mencit Akibat Pemberian Plumbun Asetat. Tesis Sekolah Pascasarjana Universitas Sumatra Utara. Medan.

Bankova, V.S., S.L.. Casro and M.C. Marcucci. 2000. Propolis: Recent Advances in Chemisty And Plant Origin. Apidologie.

Bankova, V.S., Milena P., Stefan, B. and Anna C. S. 2002. Chemical Composition of Europan Propolis : Expected and Unexpected Results Institute of Organic Chemistry with Centre of Phytochemistry, Bulgarian Academy of Sciences, 1113 Sofia, Bulgaria.

Budi, T. R. M. 2010. Dampak Induksi Karsinogenesis Glandula Mammae dengan 7, 12-dimetilbenz $(\alpha)$ antrasen terhadap Gambaran Histopatologis Lambung Tikus Sprague Dawley. Jurnal Veteriner Maret. 11 (1): 17-23.

Burdock, G.A. 1998. Review of the biological properties and toxicity of bee propolis (propolis). Food and Chemical Toxicology. 36 : 347-363.

Carrasco, L.C.E., Yesennia Sánchez-Pérez, Lucrecia Márquez Rosado, Samia Fattel-Fazenda, Evelia Arce-Popoca, Sergio Hernández-García, Saúl VillaTreviño. 2006. A single dose of caffeic acid phenethyl ester prevents initiation in a medium-term rat hepatocarcinogenesis model. World $J$ Gastroenterol. 12(42): 6779-6785.

Colon, M.V., L. Luch., A Seidel and A. Baird. 1999. Cancer Inititation by Polycyclic Aromatic Hydrocarbon. Result from Formation of Stable DNA Adducts rather than Apurinic Sites, Carcinogenesis. 20 (10): 1885-1891.

Clement, I.P., Philip, YI.P. and Lee L. Bernardis. 1980. Role of Prolactin in the Promotion of Dimethylbenz $[\alpha]$ anthracene-induced Mammary Tumors by Dietary Fat. Cancer Res 1980. 40:374-378.

Dimov V., Ivanovska N., Manolova N., Bankova V., Nikolov N., Popov S. 1991. Immunomodulatory action of propolis Influence on anti-infectious protection and macrophage function, Bulgarian Academy of Scineces, Institue of Microbiolgy, Departement of Immunology.

Donatus, I.A. 2001. Toksikologi Dasar. Laboratorium Farmakologi Dan Toksikologi. UGM. Jogyakarta.

Doll. R dan Peto, R. 1981. The causes of cancer: quantitativeestimate of avoidable risks of cancer in the United Statestoday. J. Natl. Cancer Inst. 66:1195-1308.

Gojmerac, W.L. $1983 . \quad$ Bee, Beekeeping,Honey, and Pollination. Westport: Avi.

Hasan, A.E.Z., D.J. Mangunwidjaja, T.C. Sunarti, O. Suparno, A. Setiyono. 2011. Nanopropolis Trigona spp as Anti Cancer Material. Laporan Hasil Penelitian SEAMEO-Biotrop. Bogor.

Mohanraj V.J., Chen, Y. 2006. Nanoparticles-Areview. Tropical Journal of Pharmaceutical Research. 5: 561-573.

Perez, J.R.M., Olga Beltran-Ramirez, Saul Villa-Trevino. 2012. Searching for analogues of natural Compound, Caffeic Acid Phenethyl Ester, with Chemprotective Activity, Departement of Cell Biology, Cinvestav-IPN Mexico, D.F.

Pietta P.G. Gardana C. and Pietta AM. 2002. Analytical methods for quality control of propolis. Fitoterapia 73 Suppl. I:S720.

Sariningrum. A. 2008. Pengaruh Pemberian Ekstrak Sponge Haliclona sp. Terhadap Gambaran Histopatologi Hepar Mencit Swiss. Fakultas Kedokteran Universitas Diponegoro Semarang.

Scott W., Burchiel, Davis D.A., Sidhartha D.R., Sandra L.B. 1993. DMBA induces cell death (apoptosis) in the A20.1 murine $\beta$-cell lymphoma. [abstrak] Oxford $J$ 21:120. [terhubung berkala]http://toxsci.oxfordjournals.org /cgi/content/abstract/21/1/1 $20 \quad[25$ April 2007]. 
Sforcin J.M. 2007. Propolis and the immune system; A review. Journal of Ethnopharmacology 113: 1-14.

Vijayabaskaran, K.R. Yuvaraja, G. Babu, P. Sivakumar, P. Perumal, B. Jayakar. 2010. Hepatoprotective And
Antioxidant Activity Of Symplocos Racemosa Bark Extract On DMBA Induced Hepatocellular Carcinoma In Rats. Inter J Curr Trends Sci Tech. 1(3): 147-158; 1033-1046 